\title{
ASSOCIATED FAUNA TO EICHHORNIA CRASSIPES IN A CONSTRUCTED WETLAND FOR AQUACULTURE EFFLUENT TREATMENT
}

\author{
Lúcia Helena SIPAÚBA-TAVARES *, Bruno SCARDOELLI TRUZZI *, \\ Ana MILSTEIN ** and Aline MARCARI MARQUES *
}

* São Paulo State University, Aquaculture Center, Laboratory of Limnology and Plankton Production, Via de Acesso Professor Paulo Donato Castellane s/n, CEP 14884-900, Jaboticabal SP, Brazil, sipauba@caunesp.unesp.br, brscardoeli@hotmail.com, alinemarcari@gmail.com

** Agricultural Research Organization, Fish and Aquaculture Research Station Dor, M. P. Hof HaCarmel, Israel, IL-3082000, anamilstein@agri.gov.il

DOI: 10.1515/trser-2017-0003

KEYWORDS: floating macrophytes, zooplankton, aquaculture effluents, macrofauna. ABSTRACT

Water, sediment and associated fauna were studied in a water hyacinth (Eichhornia crassipes) stand of a constructed wetland, used for aquaculture effluent treatment in SE Brazil, in February-April (summer/rainy season) and July-September (winter/dry season). The hydrological regime and decomposition processes had strong impact on the wetland water quality and on the associated fauna composition. Protozoa and Rotifera were at high densities, mainly in the dry season. Vorticella sp. was the dominant species in both seasons. Zooplankton richness, evenness and diversity were high during both seasons, with higher levels during the rainy season. Protozoa diversity and evenness were higher in the dry season when the water volume was lower. Maximum plant residence time in this wetland should be about 60 days.

RESUMEN: Fauna asociada a Eichhornia crassipes en un humedal artificial para tratamiento de efluentes de acuacultura.

Agua, sedimento y fauna asociada fueron muestreados entre las Eichhornia crassipes de un humedal artificial en el SE de Brasil usado para tratar efluentes de acuacultura, durante febrero-abril (verano/estación lluviosa) y julio-septiembre (invierno/estación seca). El régimen hidrológico y los procesos de descomposición tuvieron un fuerte impacto sobre la calidad de agua dentro del humedal y sobre la composición de la fauna asociada. Protozoa y Rotífera presentaron alta densidad, especialmente durante la estación seca. Vorticella sp. fue la única especie dominante en ambas estaciones. En ambos períodos la riqueza, uniformidad y diversidad del zooplancton fueron altas, siendo mayores en la estación lluviosa. La diversidad y uniformidad de Protozoa fueron mayores en la estación seca, cuando el volumen de agua era menor. El tiempo máximo de residencia de las plantas debería ser de unos 60 días.

REZUMAT: Fauna asociată speciei Eichhornia crassipes într-o zonă umedă artificială pentru tratarea efluenților din acvacultură.

S-au analizat apa, sedimentul și fauna asociată dintr-o parcelă de Eichhornia crassipes dintr-o zonă umedă construită pentru tratarea efluenților din acvacultură în SE Braziliei, în perioadele februarie-aprilie (vară/sezon ploios) și iulie-septembrie (iarnă/sezon secetos). Regimul hidrologic și procesele de descompunere au avut un impact puternic asupra calității apei din zona umedă precum și asupra compoziției faunistice asociate. Protozoarele şi rotiferele au prezentat densităti mari, în special pe timpul sezonului secetos. Vorticella sp. a fost singura specie dominantă din ambele sezoane. Abundența, distribuția și diversitatea zooplanctonului au fost mari în ambele sezoane, dar cu valori superioare în sezonul ploilor. Diversitatea protozoarelor și distribuția lor au fost mai ridicate în sezonul secetos, când volumul de apă a fost mai scăzut. Timpul maxim de ședere al plantelor în această zonă umedă ar trebui să fie de circa 60 zile. 


\section{INTRODUCTION}

Macrophytes and riverine vegetation perform different functions in the aquatic ecosystem, such as increasing habitat heterogeneity, providing food and shelter for many organisms and creating patches under specific physicochemical conditions (Curtean-Bănăduc et al., 2014; Gutierrez and Mayora, 2016). In turn they are affected by the growth rate, abundance and activity of those associated organisms (O'Hare et al., 2012). The organic matter retained among their roots consists of particles that can be utilized as food by the macrofauna associated with the plants, promoting a rapid circulation through the trophic web. Different species of macrophytes have been characterized by dissimilar physiological and chemical composition, which result in the release of different types of substrates that may affect the availability of ecological niches for different associated communities (Zeng et al., 2012).

Eichhornia crassipes, commonly known as water hyacinth, is an aquatic plant native to the Amazon Basin, with a high potential to retain inorganic and organic material in its biomass. Outside its native range it is often considered a problematic invasive species (Villamagna and Murphy, 2009), so that serious measures have been taken to impair its propagation, as well as to find a practical use for its large available biomass. In recent years it has received much attention due to its potential benefits for biogas production, fertilizer, water purification, as well as animal and aqua feed (Malik, 2007). E. crassipes has well-develop adventitious roots, lateral roots, and epidermal hairs, which together with its stems, leaves and stolons constitute a complex structure which offers suitable habitat or shelter for numerous organisms (Montiel-Martínez et al., 2015).

Zooplankton is a key component of freshwater ecosystems (Onciu et al., 1999) and frequently uses macrophytes as a refuge from vertebrate predators or as a substrate where to dwell and feed (Gutierrez and Mayora, 2016). Some species of the major secondary producers (Rotifera, Cladocera and Insecta larvae) are commonly found in pelagic and vegetation areas, whereas others are found in or around the vicinity of vegetation stands (Kouamé et al., 2011). Aquatic plants can be used not only as a place to grow in but also as a refuge, since they reduce mortality risk to zooplankton capable of detecting chemical cues from potential predators (Montiel-Martínez et al., 2015). In addition, macrophytes are usually covered by epiphytes that are grazed upon by several invertebrates whose diversity, abundance and distribution pattern are influenced by macrophytes (Kouamé et al., 2011).

Constructed wetlands are artificial ecosystems based on macrophytes that are widely used to treat effluents of different types. The community structure and hence the ecological functioning of these systems varies with climatic conditions. The current article investigates Eichhornia crassipes development, structure of its associated fauna and environmental conditions during the rainy and dry seasons, in the E. crassipes section of a constructed wetland used to treat effluents of an aquaculture farm.

\section{MATERIAL AND METHODS \\ Study area and sampling site}

The study was carried out in the constructed wetland for aquaculture effluents

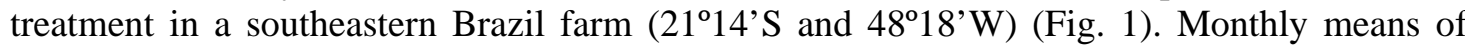
meteorological conditions during the summer/rainy season (February to April) were - air temperature: $24 \pm 1.2^{\circ} \mathrm{C}$, water temperature: $24 \pm 3.3^{\circ} \mathrm{C}$ and $85 \pm 2 \mathrm{~mm}$ rainfall; during the winter/dry season (July to September) the monthly means were $22 \pm 2.3^{\circ} \mathrm{C}, 23 \pm 3^{\circ} \mathrm{C}$ and $25 \pm$ $23 \mathrm{~mm}$. The effluent entering the wetland originated from six earthen fishponds with areas varying between 1,822 and $8,067 \mathrm{~m}^{2}$. Some fishponds received water from other smaller earthen ponds further up the watershed. The wetland also receives effluent (swine manure) 
from an anaerobic sludge blanket reactors (UASB) installed in series, with volumes ranging between 50 and $908 \mathrm{l}$, which discharged the material about once a week when reactors are switched on. During the rainy period the wetland also receives surface runoff through a channel. The wetland was $71 \mathrm{~m}$ long, with a total area of $96.6 \mathrm{~m}^{2}$, and lined with a shallow clay bottom. It was planted with three native macrophyte species, Cyperus giganteus and Typha domingensis $\left(34 \mathrm{~m}^{2}\right)$ close to the inlet water to restrain the strong water flow, mainly in the rainy season, followed by a Eichhornia crassipes $\left(32 \mathrm{~m}^{2}\right)$ stand where the associated fauna and ecological conditions were evaluated. Immediately after plant transplantation, the wetland was filled to a depth of approximately $0.30 \mathrm{~m}$. The plants were installed twice, once for the summer/rainy season (February to April) sampling and once for the winter/dry season (July to September) sampling, and were completely removed between both periods.

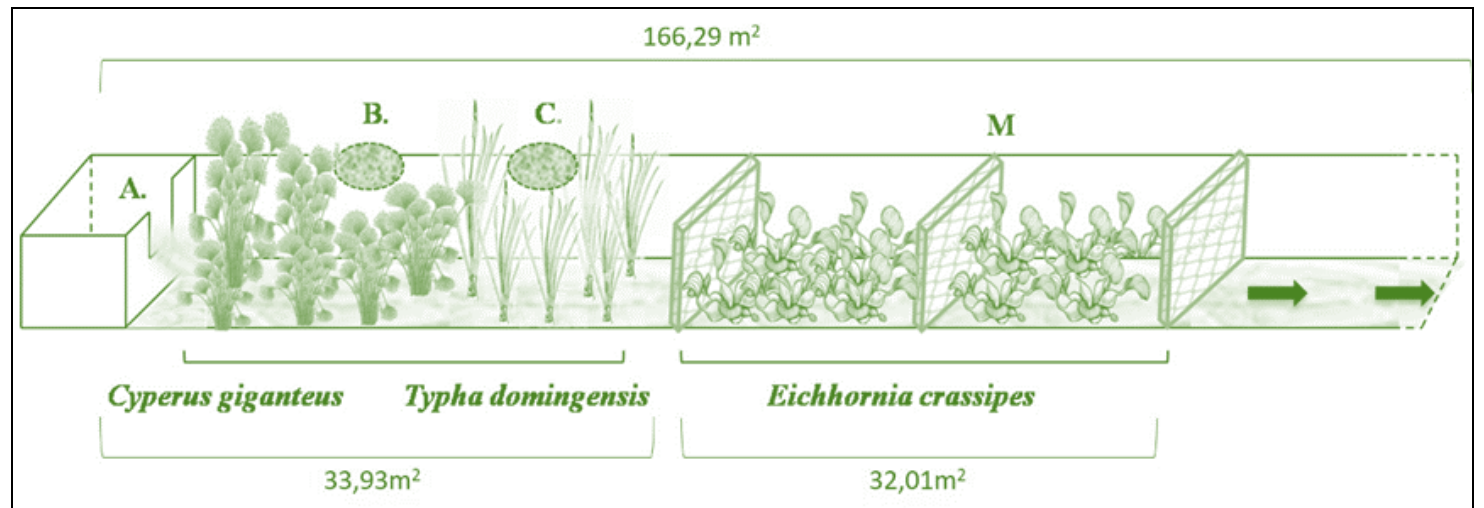

Figure 1: Diagram of the wetland system studied; $\mathrm{A}=$ effluents from the aquaculture farm, $\mathrm{B}=$ effluents from the biodigestor, $\mathrm{C}=$ rainwater input, $\mathrm{M}=$ sampling site, arrows $=$ direction of water flow

\section{E. crassipes biological data}

The growth of E. crassipes biomass was determined every fortnight during each sampling period, measuring their foliar length and width and rhizome length. Measurements were taken on the same 12 marked plants randomly chosen at the beginning of the experiment. Dry and wet masses were recorded at the end of each growth period. The plants were collected using a $0.18 \mathrm{~m}^{2}$ quadrant, dried at $60^{\circ} \mathrm{C}$ until constant weight, and weighted. Plant nutrients composition was analysed according to Bataglia et al. (1983).

\section{Associated fauna}

Samples of associated fauna were retrieved every fortnight during both periods of aquatic plant growth. All plants collected with the $0.18 \mathrm{~m}^{2}$ floating quadrant, were washed in the laboratory with distilled water using $200 \mu \mathrm{m}, 58 \mu \mathrm{m}$ and $25 \mu \mathrm{m}$ sieves. The collected fauna was preserved in $4 \%$ formalin, allowed to settle and the total collected volume measured, and stored in amber glass jars. Rotifera and Protozoa samples were analyzed with a SedgewickRafter counting cell and examined under 100X magnification. Cladocera, Copepoda, Insecta, Mollusca, Platyhelminthe, Nematoda, Ostracoda and Harpacticoida were counted in a reticulated chamber. Protozoa were grouped into two taxonomic categories: Testate amoebae (Amoebozoa and Rhizaria) and Ciliates (Ciliophora) (Adl et al., 2005). Insecta were identified at order level and Nematoda, Mollusca and Platyhelminthes at phylum level. 


\section{Water and sediment}

Surface water and sediment samples were collected every fortnight inside the E. crassipes stand. Water was sampled with a one l Van Dorn bottle and transported in refrigerated polyethylene bottles to the laboratory. Water temperature, turbidity, $\mathrm{pH}$, dissolved oxygen (DO) and conductivity were measured in situ with a Horiba U-10 multi-sensor. Total phosphorus and nitrogen compounds were quantified spectrophotometrically, following Golterman et al. (1978) and Koroleff (1976). Chlorophyll- $a$ was extracted with alcohol $90 \%$ and quantified at $663 \mathrm{~nm}$ and $750 \mathrm{~nm}$ (Nusch, 1980). Total suspended solids (TSS) and total dissolved solids (TDS) were determined according to Boyd and Tucker (1992). Water samples for microbiological analysis, using the multiple-tube methods, were collected in sterilized $500-\mathrm{ml}$ flasks and taken to the laboratory in an isothermal container. The material used in the microbiological analysis (thermotolerant coliforms) was sterilized prior to use (APHA, 1995). Vertically mixed sediment samples were retrieved with a four $\mathrm{cm}$ diameter PVC core up to approximately $10 \mathrm{~cm}$ deep. Sediments were air dried, gently disaggregated and dried in a convection oven at $70^{\circ} \mathrm{C}$ until completely dry. Determinations of organic matter (OM), Ca, $\mathrm{Mg}, \mathrm{P}, \mathrm{K}, \mathrm{N}, \mathrm{Fe}, \mathrm{Zn}$ and $\mathrm{pH}$ were performed according to methods described by Raij et al. (2001). Analyses were performed immediately after sampling or when necessary samples were duly stored under refrigeration.

\section{Data analysis}

All data underwent one-way analysis of variance (ANOVA) with the Statistica 10 package, to test differences between seasons (Statsoft, 2011). Differences were considered significant at $\mathrm{p}<0.05$. All results were expressed as means \pm SD (Standard Deviation). Pearson correlation coefficients were calculated among environmental variables. Associated fauna diversity was calculated with the Shannon-Wiener (H') index (Pielou, 1975). Richness (S) was calculated as the total number of species present and evenness or equitability (E) was determined as $\mathrm{H} / \mathrm{H}$ max, where $\mathrm{H}$ is the Shannon-Wiener index and $\mathrm{H}$ max $=\ln \mathrm{S}$. Species dominance (D) and abundance (A) were analyzed for organisms associated to macrophyte. Species were considered dominant when the density was higher than $50 \%$ of the total number of specimens present in the sample; they were abundant when the number of specimens was higher than the mean density of all occurring species (Lobo and Leighton, 1986).

Table 1: Water quality in the constructed wetland: Mean \pm SD in the rainy and dry seasons ${ }^{*}$ and list of variables significantly correlated with each variable ${ }^{* *}$.

\begin{tabular}{|l|c|c|c|c|}
\hline Variables & Rainy season & Dry season & $\begin{array}{c}\text { Variable } \\
\text { positively } \\
\text { correlated } \\
\text { with }\end{array}$ & $\begin{array}{c}\text { Variable } \\
\text { negatively } \\
\text { correlated with }\end{array}$ \\
\hline temperature $\left({ }^{\circ} \mathrm{C}\right)$ & $25.4 \pm 1.6^{\mathrm{a}}$ & $20.8 \pm 1.8^{\mathrm{b}}$ & $\mathrm{TSS}$ & $\begin{array}{c}\text { cond, } \mathrm{DO}, \mathrm{NO}_{3}, \\
\text { TDS }\end{array}$ \\
\hline pH & $6.7 \pm 0.1^{\mathrm{a}}$ & $6.8 \pm 0.5^{\mathrm{a}}$ & $\mathrm{NO}_{3}$ & $\mathrm{PO}_{4}$, Tot P \\
\hline $\begin{array}{l}\text { Conductivity } \\
\left(\mu S . \mathrm{cm}^{-1}\right)\end{array}$ & $93 \pm 19^{\mathrm{a}}$ & $105 \pm 15^{\mathrm{a}}$ & & tem \\
\hline turbidity $(\mathrm{NTU})$ & $21.6 \pm 15.1^{\mathrm{a}}$ & $20.2 \pm 5.6^{\mathrm{a}}$ & colif, chlor & \\
\hline alkalinity $\left(\mathrm{mg} . \mathrm{l}^{-1}\right)$ & $54 \pm 6.0^{\mathrm{a}}$ & $50 \pm 3.7^{\mathrm{a}}$ & & tem \\
\hline DO $\left(\mathrm{mg} . \mathrm{l}^{-1}\right)$ & $2.9 \pm 1.3^{\mathrm{b}}$ & $5.3 \pm 1.9^{\mathrm{a}}$ & $\mathrm{NO}_{3}$ & \\
\hline TAN $\left(\mu \mathrm{g} . \mathrm{l}^{-1}\right)$ & $550 \pm 167^{\mathrm{a}}$ & $818 \pm 615^{\mathrm{a}}$ & $\mathrm{NO}_{2}, \mathrm{PO}_{4}, \mathrm{Tot}$ & $\mathrm{P}$ \\
\hline
\end{tabular}


Table 1 (continued): Water quality in the constructed wetland: Mean \pm SD in the rainy and dry seasons ${ }^{*}$ and list of variables significantly correlated with each variable ${ }^{* *}$.

\begin{tabular}{|l|c|c|c|c|}
\hline Variables & Rainy season & Dry season & $\begin{array}{c}\text { Variable } \\
\text { positively } \\
\text { correlated } \\
\text { with }\end{array}$ & $\begin{array}{c}\text { Variable } \\
\text { negatively } \\
\text { correlated } \\
\text { with }\end{array}$ \\
\hline $\mathrm{NO}_{2}\left(\mu \mathrm{g} . \mathrm{l}^{-1}\right)$ & $11.5 \pm 6.7^{\mathrm{a}}$ & $13.9 \pm 6.5^{\mathrm{a}}$ & TAN, Tot P & \\
\hline $\mathrm{NO}_{3}\left(\mu \mathrm{g} . \mathrm{l}^{-1}\right)$ & $37.8 \pm 31^{\mathrm{b}}$ & $150 \pm 95^{\mathrm{a}}$ & $\mathrm{pH}, \mathrm{DO}, \mathrm{TDS}$ & tem \\
\hline $\mathrm{PO}_{4}\left(\mu \mathrm{g} . \mathrm{l}^{-1}\right)$ & $19.8 \pm 9.0^{\mathrm{a}}$ & $48 \pm 68^{\mathrm{a}}$ & $\mathrm{TAN}, \mathrm{Tot} \mathrm{P}$ & $\mathrm{pH}$ \\
\hline${\text { Total P }\left(\mu \mathrm{g} . \mathrm{l}^{-1}\right)}^{38.6 \pm 19^{\mathrm{a}}}$ & $86 \pm 125^{\mathrm{a}}$ & TAN, $\mathrm{NO}_{2}, \mathrm{PO}_{4}$ & $\mathrm{pH}$ \\
\hline BOD $\left(\mathrm{mg} . \mathrm{l}^{-1}\right)$ & $57 \pm 54^{\mathrm{a}}$ & $83 \pm 47^{\mathrm{a}}$ & $\mathrm{TDS}$ & \\
\hline TSS $\left(\mathrm{mg} . \mathrm{l}^{-1}\right)$ & $12.6 \pm 4.1^{\mathrm{a}}$ & $8.4 \pm 2.9^{\mathrm{a}}$ & tem, colif, chlor & TDS \\
\hline TDS $\left(\mathrm{mg} . \mathrm{l}^{-1}\right)$ & $180 \pm 57^{\mathrm{a}}$ & $364 \pm 188^{\mathrm{a}}$ & $\mathrm{NO}_{3}, \mathrm{BOD}$ & tem, TSS \\
\hline coliforms $(\mathrm{MPN})$ & $19.512 \pm 41.644^{\mathrm{a}}$ & $542 \pm 462^{\mathrm{a}}$ & turb, TSS, chlor & \\
\hline chlorophyll- $a\left(\mu \mathrm{g} . \mathrm{l}^{-1}\right)$ & $80 \pm 76^{\mathrm{a}}$ & $39 \pm 22^{\mathrm{a}}$ & turb, TSS, colif & \\
\hline
\end{tabular}

${ }^{*}$ In each row, means followed by the same letter do not significantly differ $(\mathrm{p}<0.05)$.

${ }^{* * *}$ Pearson Correlation at least $\mathrm{p}<0.05$.

\section{RESULTS}

The water quality parameters (Tab. 1) showed significant differences between seasons only for temperature, dissolved oxygen and nitrate. Water temperature was higher in the rainy summer, while oxygen and nitrate were higher in the dry winter. There were significant positive correlations among TSS, coliforms, chlorophyll- $a$ and turbidity, which indicates that phytoplankton and bacteria formed an important portion of the particles flowing in the wetland water. There were significant positive correlations among TAN, nitrite, phosphate and total phosphorus, which indicates that decomposition processes strongly affected water quality in the wetland. The lack of correlation among oxygen, $\mathrm{pH}$ and chlorophyll-a indicates that photosynthesis by phytoplankton had little effect on the water quality flowing through the wetland, at least as compared with the strong effect of decomposition.

In the sediment, significant differences between seasons were observed for organic matter, $\mathrm{Ca}$ and $\mathrm{N}$, which were higher during in the dry season, and for $\mathrm{K}$, which was higher during the rainy season (Tab. 2). The $\mathrm{pH}$ of the sediment was acidic and the highest nutrient concentration was observed for Ca in the dry season (Tab. 2).

E. crassipes reached $50-55 \mathrm{~cm}$ total length (rizoma + aerial plant) in 60 days of growth, in either the rainy or in the dry season (Fig. 2). Nutrients in the aquatic plants biomass were much higher than those observed in the sediment, indicating incorporation of these nutrients in their growth. Nutrients in the plant biomass were higher during the dry season, except for $\mathrm{Mg}$, Fe and $\mathrm{Zn}$. The highest nutrient concentrations in the aquatic plants were of $\mathrm{K}$. The opposite occurred with $\mathrm{K}$ in the sediment, which was below 0.1 g. $\mathrm{m}^{-2}$ (Tab. 2). Plants wet biomass was higher during the dry season, whereas plants dry biomass was similar in both seasons (Tab. 2). 
Table 2: Mean and SD concentrations * of variables measured in sediment and E. crassipes plants during the rainy and dry seasons.

\begin{tabular}{|c|c|c|}
\hline Variables & Rainy season & Dry season \\
\hline \multicolumn{3}{|l|}{ Sediment (g. dm ${ }^{-3}$ ) } \\
\hline $\mathrm{N}$ & $0.64 \pm 0.19^{b}$ & $1.08 \pm 0.33^{\mathrm{a}}$ \\
\hline $\mathrm{P}$ & $0.08 \pm 0.03^{\mathrm{a}}$ & $0.09 \pm 0.01^{\mathrm{a}}$ \\
\hline K & $0.06 \pm 0.001^{\mathrm{a}}$ & $0.05 \pm 0.002^{b}$ \\
\hline $\mathrm{Ca}$ & $1.81 \pm 1.19^{b}$ & $2.20 \pm 0.51^{\mathrm{a}}$ \\
\hline $\mathrm{Mg}$ & $0.24 \pm 0.10^{\mathrm{a}}$ & $0.24 \pm 0.04^{\mathrm{a}}$ \\
\hline $\mathrm{Fe}$ & $0.11 \pm 0.01^{\mathrm{a}}$ & $0.12 \pm 0.02^{\mathrm{a}}$ \\
\hline $\mathrm{Zn}$ & $0.003 \pm 0.002^{\mathrm{a}}$ & $0.006 \pm 0.003^{\mathrm{a}}$ \\
\hline Organic Matter & $15.0 \pm 3.9^{b}$ & $29.8 \pm 9.4^{\mathrm{a}}$ \\
\hline $\mathrm{pH}$ & $5.2 \pm 0.5^{\mathrm{a}}$ & $5.4 \pm 0.2^{\mathrm{a}}$ \\
\hline \multicolumn{3}{|l|}{ Plant (g. $\mathrm{m}^{-2}$ ) } \\
\hline $\mathrm{N}$ & $8.3 \pm 4.9^{b}$ & $10.4 \pm 6.2^{\mathrm{a}}$ \\
\hline $\mathrm{P}$ & $1.0 \pm 0.7^{b}$ & $1.5 \pm 1.1^{\mathrm{a}}$ \\
\hline $\mathrm{K}$ & $24.0 \pm 18.8^{b}$ & $30.6 \pm 18.8^{\mathrm{a}}$ \\
\hline $\mathrm{Ca}$ & $4.5 \pm 2.6^{b}$ & $5.0 \pm 2.7^{\mathrm{a}}$ \\
\hline $\mathrm{Mg}$ & $1.5 \pm 0.8^{\mathrm{a}}$ & $1.7 \pm 0.7^{\mathrm{a}}$ \\
\hline $\mathrm{Fe}$ & $3.9 \pm 2.4^{\mathrm{a}}$ & $1.6 \pm 0.9^{\mathrm{b}}$ \\
\hline $\mathrm{Zn}$ & $0.05 \pm 0.03^{\mathrm{a}}$ & $0.05 \pm 0.03^{\mathrm{a}}$ \\
\hline Wet mass & $7,698 \pm 4,880^{b}$ & $9,875 \pm 5,709^{\mathrm{a}}$ \\
\hline Dry mass & $339 \pm 185^{\mathrm{a}}$ & $368 \pm 184^{\mathrm{a}}$ \\
\hline
\end{tabular}

"In each row, means followed by the same letter do not significantly differ $(\mathrm{p}<0.05)$

The E. crassipes associated zooplankton community comprised 51 taxa, 43 Rotifera, three Cladocera, four Copepoda, and one Ostracoda. Insecta consisted of six orders and Protozoa comprised seven genera. The phyla Nematoda, Mollusca and Platyhelminthes had low contribution. Diversity and species abundance were higher in the rainy season (Tab. 3) due to the contributions of allochthonous material from the fish ponds. Total density was $33 \%$ lower in the dry compared with the rainy season. The most abundant organisms were Protozoa, among which Ciliophora comprised over two thirds of the total organisms collected, followed by Rotifera with $22 \%$ of the total organisms in the rainy season and $14 \%$ in the dry season (Fig. 3). Vorticella sp. was the only dominant species in both seasons. Arcella sp. (Protozoa), Proales doliares and Lecane bulla (Rotifera) were abundant in both seasons (Tab. 4). During the dry season only Rotifera and Protozoa occurred in the E. crassipes associated fauna, with dominance of Vorticella sp. Species of Cladocera were abundant or present during the rainy season, albeit absent in the dry season. The opposite was observed for the adult and nauplii Copepoda Argyrodiaptomus furcatus. The associated fauna tended to have high zooplankton species richness (above 46 species), evenness (above 0.66) and diversity (Shannon-Wiener index with 3.45 and 2.44 nats ind ${ }^{-1}$ ) during the rainy and the dry seasons (Tab. 3). 
Table 3: Volume of associated fauna washed out from the E. crassipes growing in a $0.18 \mathrm{~m}$ area (range), and average density ${ }^{*}$, species richness, evenness and Shanon-Wiener diversity (H’) index in each season.

\begin{tabular}{|c|c|c|}
\hline & Rainy season & Dry season \\
\hline Associated fauna volume (ml) & $1,440-1,820$ & $1,160-1,600$ \\
\hline Zooplankton total & $1,107,500$ & 413,500 \\
\hline Cladocera (ind. $\mathrm{m}^{-2}$ ) & 109,800 & 0 \\
\hline Copepoda (ind. $\mathrm{m}^{-2}$ ) & 24,000 & 800 \\
\hline Ostracoda (ind. $\mathrm{m}^{-2}$ ) & 9,700 & 1,500 \\
\hline Rotifera (ind. $\mathrm{m}^{-2}$ ) & 964,000 & 411,200 \\
\hline Richness & 51 & 46 \\
\hline Evenness & 0.88 & 0.66 \\
\hline Diversity (H') & 3.45 & 2.44 \\
\hline Protozoa total (ind. $\mathrm{m}^{-2}$ ) & $3,287,000$ & $2,558,000$ \\
\hline Amoebozoa (ind. $\mathrm{m}^{-2}$ ) & 152,000 & 120,000 \\
\hline Rhizaria (ind. $\mathrm{m}^{-2}$ ) & 72,000 & 53,000 \\
\hline Ciliophora (ind. $\mathrm{m}^{-2}$ ) & $3,063,000$ & $2,385,000$ \\
\hline Richness & 8 & 7 \\
\hline Evenness & 0.12 & 0.16 \\
\hline Diversity (H’) & 0.46 & 0.60 \\
\hline Insecta total & 4,654 & 90 \\
\hline Collembola (ind. $\mathrm{m}^{-2}$ ) & 3 & 0 \\
\hline Coleoptera (ind. $\mathrm{m}^{-2}$ ) & 57 & 8 \\
\hline Diptera (ind. $\mathrm{m}^{-2}$ ) & 4,500 & 25 \\
\hline Hemiptera (ind. $\mathrm{m}^{-2}$ ) & 6 & 30 \\
\hline Neuroptera (ind. $\mathrm{m}^{-2}$ ) & 0 & 1 \\
\hline Odonata (ind. $\mathrm{m}^{-2}$ ) & 88 & 26 \\
\hline Richness & 6 & 5 \\
\hline Evenness & 0.37 & 0.25 \\
\hline Diversity (H') & 1.42 & 0.92 \\
\hline Others total & 3,936 & 3,550 \\
\hline Nematoda (ind. $\mathrm{m}^{-2}$ ) & 3,600 & 2,300 \\
\hline Mollusca (ind. $\mathrm{m}^{-2}$ ) & 36 & 850 \\
\hline Platyhelminthes (ind. $\mathrm{m}^{-2}$ ) & 300 & 400 \\
\hline Richness & 3 & 3 \\
\hline Evenness & 0.09 & 0.24 \\
\hline Diversity (H') & 0.36 & 0.89 \\
\hline
\end{tabular}

*ind. $\mathrm{m}^{-2}$ of E. crassipes. 


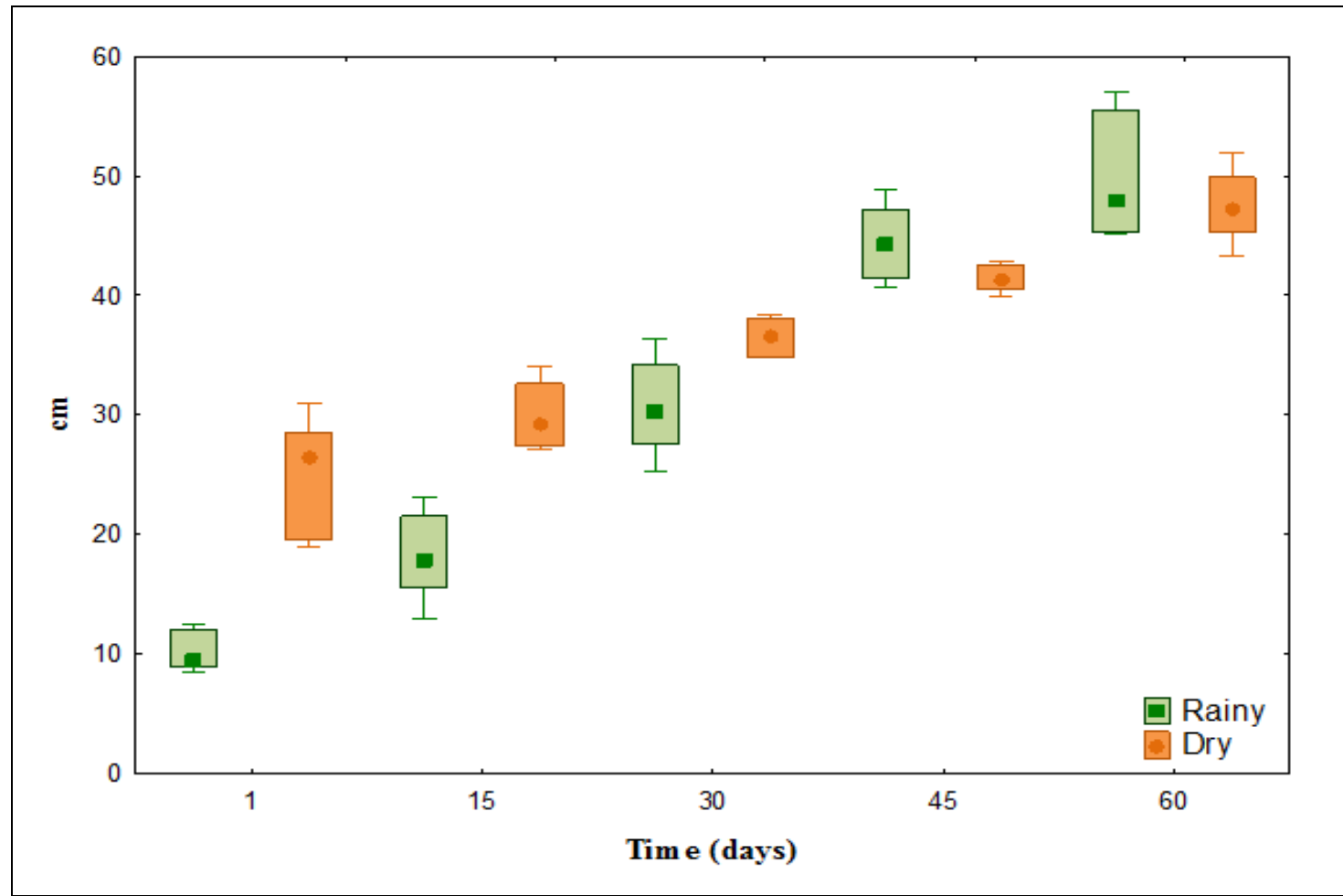

Figure 2: Total length (rizoma + aerial plant) growth of Eichhornia crassipes during the rainy and dry seasons. Measurements are mean \pm SD of 12 plants.

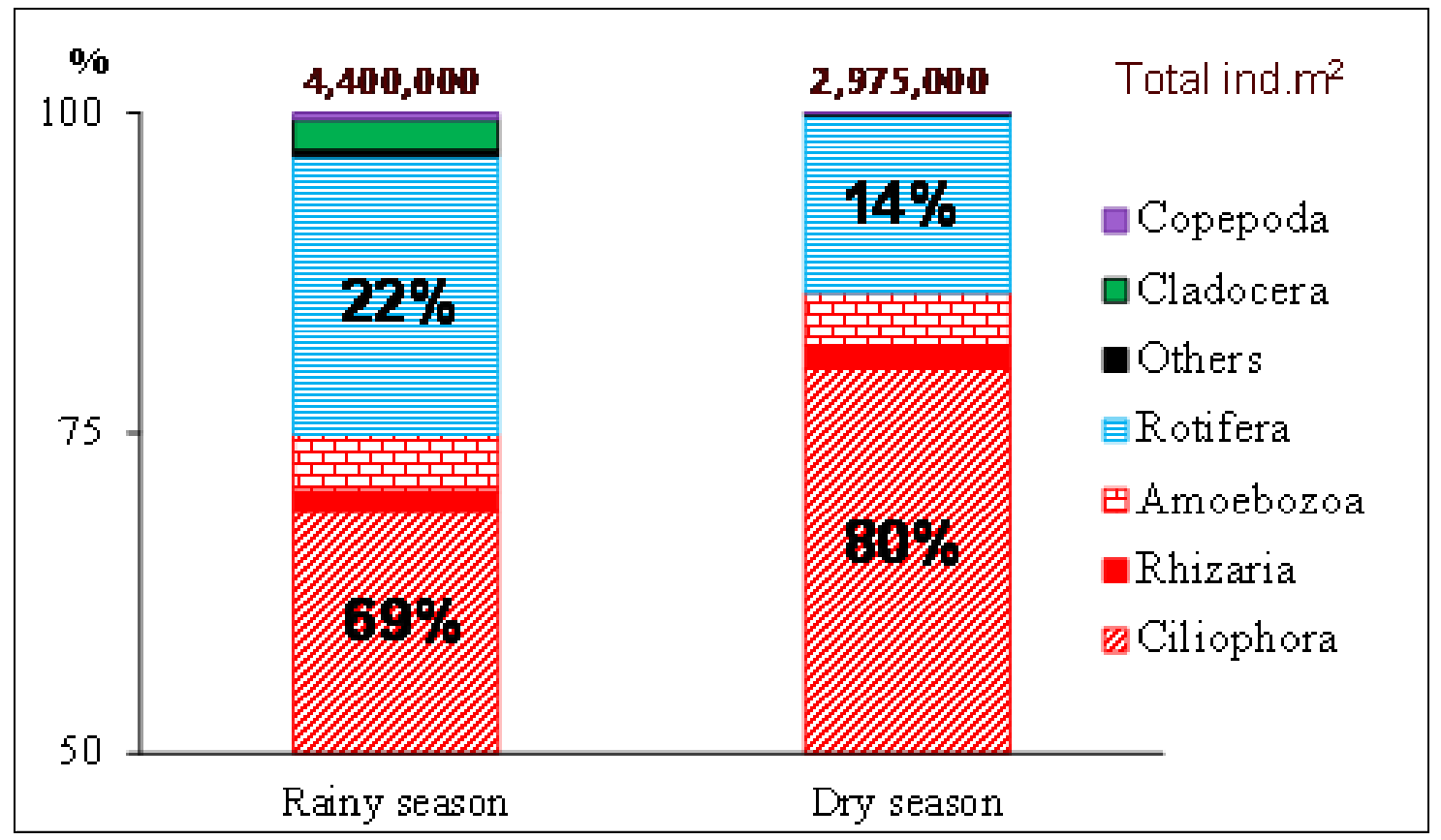

Figure 3: Relative abundance of E. crassipes associated fauna and average total density recorded in the rainy and dry seasons. Note that the $\mathrm{x}$-axis starts at $50 \%$.

Others = Insecta, Ostracoda, Nematoda, Mollusca and Plathyelminthes. 
Table 4: Frequency of occurrence ${ }^{*}$ of associated fauna to E. crassipes in the rainy and dry seasons.

\begin{tabular}{|c|c|c|}
\hline Taxa & Rainy season & Dry season \\
\hline \multicolumn{3}{|l|}{ Cladocera } \\
\hline Alona guttata (Sars, 1862) & A & - \\
\hline Ilyocryptus spinifer (Herrick, 1882) & A & - \\
\hline Diaphanosoma birgei (Korinek, 1981) & + & - \\
\hline \multicolumn{3}{|l|}{ Copepoda } \\
\hline Thermocyclops decipiens (Kiefer, 1929) & + & + \\
\hline Thermocyclops minutus (Lowndes, 1934) & + & + \\
\hline nauplii & A & + \\
\hline Argyrodiaptomus furcatus (Sars, 1901) & - & + \\
\hline nauplii & - & + \\
\hline Harpacticoida & + & + \\
\hline Ostracoda & + & + \\
\hline \multicolumn{3}{|l|}{ Rotifera } \\
\hline Ascomorpha ovalis (Bergendal, 1892) & - & A \\
\hline Ascomorpha saltans (Bartsch, 1870) & + & + \\
\hline Asplanchnopus sp. (Guerne, 1888) & + & $\mathrm{A}$ \\
\hline Brachionus falcatus (Zacharias, 1898) & + & - \\
\hline Brachionus calyciflorus (Pallas, 1766) & - & + \\
\hline Cephalodella misgurnus (Wulfert, 1937) & + & + \\
\hline Cephalodella gibba (Ehrenberg, 1830) & + & A \\
\hline Collotheca mutabilis (Hudson, 1885) & + & + \\
\hline Collotheca ornata (Ehrenberg, 1832) & + & + \\
\hline Colurella obtusa (Gosse, 1886) & A & + \\
\hline Colurella uncinata (Müller, 1773) & A & + \\
\hline Conochilus sp. (Ehrenberg, 1834) & - & + \\
\hline Dipleuchlanis propatula (Gosse, 1886) & - & + \\
\hline Euchlanis dilatata (Hauer, 1930) & + & A \\
\hline Epiphanes macrourus (Barrois and Daday, 1894) & + & + \\
\hline Filinia opoliensis (Zacharias, 1898) & + & - \\
\hline Heterolepadella heterostyla (Murray, 1914) & + & + \\
\hline Keratella cochlearis (Gosse, 1851) & - & + \\
\hline Keratella tropica (Apstein, 1907) & - & + \\
\hline Lecane aculeata (Jakubski, 1912) & + & + \\
\hline Lecane bulla (Grosse, 1851) & A & A \\
\hline Lecane calcaria (Harring and Myers, 1926) & - & + \\
\hline Lecane cornuta (Müller, 1786) & + & + \\
\hline Lecane curvicornes (Murray, 1913) & + & + \\
\hline Lecane furcata (Murray, 1913) & + & + \\
\hline Lecane hornemanni (Ehrenberg, 1834) & + & + \\
\hline Lecane inermis (Bryce, 1892) & - & + \\
\hline Lecane ludwigii (Eckstein, 1883) & + & + \\
\hline Lecane lunaris (Ehrenberg, 1832) & A & + \\
\hline
\end{tabular}


Table 4 (continued): Frequency of occurrence ${ }^{*}$ of associated fauna to E. crassipes in the rainy and dry seasons.

\begin{tabular}{|c|c|c|}
\hline Taxa & Rainy season & Dry season \\
\hline Lecane monostyla (Daday, 1897) & + & + \\
\hline Lecane proiecta (Hauer, 1956) & + & + \\
\hline Lecane signifera (Jennings, 1896) & + & + \\
\hline Lepadella sp. (Bory de St. Vincent, 1826) & + & + \\
\hline Philodina sp. (Ehrenberg, 1830) & + & + \\
\hline Proalinopsis caudatus (Collins, 1873) & + & $\mathrm{A}$ \\
\hline Proales doliaris (Rousselet, 1895) & A & A \\
\hline Proales globulifera (Hauer, 1921) & + & + \\
\hline Ptygura fucillata (Kellicott, 1889) & - & + \\
\hline Synchaeta stylata (Wierzejski, 1893) & - & + \\
\hline Testudinella patina (Hermann, 1783) & + & + \\
\hline Testudinella sp. & + & + \\
\hline Trichocerca cavia (Gosse, 1886) & + & + \\
\hline Trichocerca similis (Wierzejski, 1893) & + & + \\
\hline \multicolumn{3}{|l|}{ Protozoa } \\
\hline \multicolumn{3}{|l|}{ Amoebozoa } \\
\hline Arcella sp. & A & $\mathrm{A}$ \\
\hline Centropyxis sp. & + & + \\
\hline Difflugia sp. & + & - \\
\hline Euplotes sp. & - & + \\
\hline \multicolumn{3}{|l|}{ Rhizaria } \\
\hline Euglypha sp. & $\mathrm{A}$ & + \\
\hline \multicolumn{3}{|l|}{ Ciliophora } \\
\hline Paramecium sp. & A & + \\
\hline Vorticella sp. & $\mathrm{D}$ & $\mathrm{D}$ \\
\hline \multicolumn{3}{|l|}{ Insecta } \\
\hline Collembola & + & - \\
\hline Coleoptera & + & + \\
\hline Diptera & + & + \\
\hline Hemiptera & + & + \\
\hline Neuroptera & - & + \\
\hline Odonata & + & + \\
\hline \multicolumn{3}{|l|}{ Others } \\
\hline Nematoda & + & + \\
\hline Mollusca & + & + \\
\hline Platyhelminthes & + & + \\
\hline
\end{tabular}

${ }^{*}+=$ present; - = absent; $\mathrm{A}$ = abundant; $\mathrm{D}$ = dominant. 


\section{DISCUSSION}

The water quality in the constructed wetland was very variable during each studied period, so that most of the environmental parameters measured did not show significant differences between the rainy and the dry seasons. The rainy season is during summer and the dry one during winter, which accounts for the water temperature differences between seasons. The significantly higher oxygen and nitrate concentrations in the dry than in the rainy seasons are at least partially accounted for by differences in the hydrological regime during both seasons. The rainy season is also the main fish culture period in the aquaculture farm, so that the constructed wetland received, together with rain and surface runoff, increased amounts of effluents (with organic matter that consumed oxygen). During this period, the water flow and turbulence inside the wetland were strong and the water outflow contained large amounts of particles. Under these conditions nitrification was reduced due to loss of nitrifying bacteria attached to the washed out particles, resulting in the observed reduced nitrate concentration in the water. Reduced nitrification related to washout were already observed in flow-through fish culture systems with high water exchange rates (Diab et al., 1992; Milstein et al., 2001) and even in stagnant fishponds flooded and washed out by heavy monsoon rains (Milstein et al., 2002). Together with this, numerous insects and rather large aquatic organisms that can withstand water turbulence and washout (crustaceans, mollusks, and helminths) were abundantly found in the E. crassipes associated fauna. On the contrary, during the dry season less effluents and few surface runoff entered the wetland (less oxygen consumption) so that water flow and turbulence in the constructed wetland were low allowing sedimentation of most particles and reducing particles washout from the system. Under these conditions nitrifying bacteria remained in the wetland, increasing nitrate levels in the water, as well as the small organisms (protozoa and rotifers) that dominated in the E. crassipes associated fauna.

In this flow-through system, phytoplankton entering with the effluents encountered an unfavorable environment within the wetland due to macrophytes shadowing and competition for nutrients, and also were rather quickly washed out. Thus, phytoplankton photosynthesis had little effect on the wetland water quality, as indicated by the lack of correlation among oxygen, $\mathrm{pH}$ and chlorophyll- $a$. The high loading of organic matter entering with the aquaculture ponds and UASB effluents and particle trapping by the macrophytes should have favored decomposition processes, as indicated by the significant positive correlations among the decomposition products TAN, nitrite and phosphate recorded in the water sampled among the macrophytes. The thermotolerant coliforms get it these effluents should have fostered a detrital food net where tiny in size rotifers, protozoa, and cyclopoid copepod nauplii have a successful competing favored position in this circumstance.

Protozoa, the most abundant organisms in this study, are widespread in wetland rhizospheres where feeding on roots and microorganisms is enhanced (Neori and Agami, 2016). Arcellidae is one of the predominant families, coupled with Difflugiidae and Centropyxidae in the community structures of wetland environments (Lansac-Tôha et al., 2014). High dominance of Vorticella sp. during the sampled period shows that the free-living ciliophorans are commonly encountered in fish ponds. However, when fish are stressed by adverse environmental conditions, the ciliophorans become a facultative ectoparasite (AbdelBaki et al., 2014). According to Mieczan (2007), populations of Protozoa in aquatic environments are directly related to the presence of suspended solids produced by fast life cycle macrophytes, such as E. crassipes. 
Rhizosphere invertebrates function ecologically as Protozoa in the consumption of exudates, biota, flora and root tissue, by modifying nutrients and influencing plant growth (Neori and Agami, 2016). The continuous growth of the plants until the end of each sampled period provided a large abundance of associated organisms, mainly during the rainy season.

E. crassipes provides an extra habitat for macro- and micro-invertebrates due to its large radicular system available in the water column, which traps particles and is used as both food and substrate (Chowdhary and Sharma, 2013). The observed large diversity, richness and evenness of zooplankton in the E. crassipes associated fauna were mainly related to rotifer species. Rotifers predominate in environments with human activities since they reproduce and rapidly adapt themselves to environmental changes (Dahms et al., 2011). The large abundance of rotifer species recorded is related to the large water volumes containing them, which the wetland received from several aquaculture ponds (Sipaúba-Tavares and Dias, 2014).

E. crassipes submerged and areal parts provide appropriate habitat and trophic resources for insects. At least for Diptera and Odonata assemblages, it was reported that the aquatic plants support assemblages of these insects, abundance and richness of which depend on the abundance and distribution of the vegetation (Capello et al., 2013).

The ecological indexes were higher in the rainy season for zooplankton and Insecta as a result of high water flow from the different fish ponds during that period. This occurred because the aquaculture farm has a continuous water flow of which about $60 \%$ of the water volume goes to the wetland under analysis. However, the diversity and evenness of Protozoa species were higher during the dry season when the water volume was lower and species stabilized at the E. crassipes roots. After 60 days, plants in the wetland had to be removed due to lack of space for their development. Consequently, maximum residence time of the plant in this wetland should be approximately 60 days, with complete regular harvest to maintain the retention and incorporation of water nutrients into the plants biomass.

\section{ACKNOWLEDGEMENTS}

The authors would like to thank the Foundation for Research Support of the State of São Paulo (FAPESP) for funding (14/24697-3) and for the scholarship to the last author (14/08186-9). Thanks are also due to Brazilian Council for Scientific and Technological Development (CNPq) and to Carbonin E. R. for counting insect organisms. 


\section{REFERENCES}

1. Abdel-Baki A. A. S., Gewik M. M. and Al-Quraishy S., 2014 - First records of Ambiphrya and Vorticella spp. (Protozoa, Ciliophora) in cultured Nile tilapia (Oreochromis niloticus) in the central region of Saudi Arabia, Saudi Journal of Biological Sciences, 21, 520-523.

2. Adl S. M., Simpson A. G. B., Farmer M. A., Andersen R. A., Anderson O. R., Barta J. R., Bowser S. S., Brugerolle G., Fensome R. A., Fredericq S., James T. Y., Karpov S., Kugrens P., Krug J., Lane C. E., Lewis L. A., Lodge J., Lynn D. H., Mann D. G., Mccourt R. M., Mendoza L., Moestrup O., Mozley-Standridge S. E., Nerad T. A., Shearer C. A., Smirnov A. V., Spiegel F. W. and Taylor M. F. J. R., 2005 - The new higher level classification of eukaryotes with emphasis on the taxonomy of Protists, Journal of Eukaryotes Microbiology, 52, 399-451.

3. APHA, 1995 - Standard methods for the examination of water and wastewater, 19th Ed. Washington: APHA, 1100.

4. Bataglia O. C., Furlani A. M. C., Teixeira J. P. F., Furlani P. R. and Gallo J. R., 1983 Chemical analysis methods for plants, Boletim Técnico: Instituto Agronômico, 78, Campinas, 48. (in Portuguese)

5. Curtean-Bănăduc A., Schneider-Binder E. and Bănăduc D., 2014 - The importance of the riverine ligneous vegetation for the Danube Basin lotic ecosystems, in Cianfaglione K. (ed.), L’importanza degli Alberi e del Bosco, Cultura, scienza e coscienza del territorio, Temi Edit., Trento, Italia, ISBN: 978-88-973772-63-9, I-II, 187-210.

6. Boyd C. E. and Tucker C. S., 1992 - Water quality and pond soil analyses for aquaculture, Auburn: Alabama Agricultural Experiment Station, 183.

7. Capello S., Marchese M. and De Wysiecki M. L., 2013 - Orthoptera assemblages associated with macrophytes of floodplain lakes of the Paraná River, Revista Brasileira de Entomologia, 57, 1, 59-66.

8. Chowdhary S. and Sharma K. K., 2013 - Eichhornia crassipes as a most preferred habitat for macrobenthic invertebrates, Journal of Pharmaceutical and Scientific Innovation, 2, 4, 70-72.

9. Dahms H. U., Hagiwara A. and Lee J. S., 2011 - Ecotoxicology, ecophysiology and mechanistic studies with rotifers, Aquatic Toxicology, 101, 1, 1-12.

10. Diab S., Kochba M., Mires D. and Avnimelech Y., 1992 - Combined intensive-extensive (CIE) pond system, A: norganic nitrogen transformations, Aquaculture, 101, 33-39.

11. Golterman H. L., Clymo R. S., Ohnstad M. A. M., 1978 - Methods for physical and chemical analysis of fresh water, Oxford: Blackwell Scientific Publication, 214.

12. Gutierrez M. F. and Mayora G., 2016 - Influence of macrophyte integrity on zooplankton habitat preferred, emphasizing the released phenolic compounds and chromophoric dissolved organic matter, Aquatic Ecology, 50, 1, 137-151.

13. Koroleff F., 1976 - Determination of nutrients, in Grashof E. and Kremling E., orgs, Methods of seawater analysis, Verlag Chemie Wenhein, 181.

14. Kouamé M. K., Dietoa M. Y., Edia E. O., DaCosta S. K., Quattara A. and Gourène G., 2011 Macroinvertebrate communities associated with macrophyte habits in a tropical man-made lake (Lake Taabo, Côte d'Ivoire), Knowledge and Management of Aquatic Ecosystems, 400, 03, DOI: http://dx.doi.org/10.1051/kmae/2010035.

15. Lansac-Tôha F., Velho L. F. M., Costa D. M., Simões N. R. and Alves G. M., 2014 Structure of the testate amoeba community in different habitats in a neotropical floodplain, Brazilian Journal Biology, 74, 1, 181-190.

16. Lobo E. and Leighton G., 1986 - Estructuras comunitarias de las fitocenosis planctonicas de los sistemas de desembocaduras de ríos y esteros de la zona central de Chile, Revista de Biología Marina y Oceanografía, 22, 1, 1-29.

17. Malik A., 2007 - Environmental challenge vis a vis opportunity: The case of water hyacinth, Environment International, 33, 1, 122-138. 
18. Mieczan T., 2007 - Size spectra and abundance of planktonic ciliates within various habitats in a macrophyte-dominated lake (Eastern Poland), Biologia, 62, 2, 189-194.

19. Milstein A., Wahab M. A. and Rahman M. M., 2002 - Environmental effects of common carp Cyprinus carpio (L.) and mrigal Cirrhinus mrigala (Hamilton) as bottom feeders in major Indian carp polycultures, Aquaculture Research, 33, 1103-1117.

20. Milstein A., Zoran M., Kochba M. and Avnimelech Y., 2001 - Effect of different management practices on water quality of tilapia intensive culture systems in Israel, Aquaculture International, 9, 133-152.

21. Montiel-Martínez A., Ciros-Pérez J. and Corkidi G., 2015 - Littoral zooplankton-water hyacinth interactions: habitat or refuge? Hydrobiologia, 755, 1, 173-182.

22. Neori A. and Agami M., 2016 - The Functioning of Rhizosphere Biota in Wetlands - a Review, Wetlands, doi: 10.1007/s13157-016-0757-4.

23. Nusch E. A. 1980 - Comparison of different methods for chlorophyll and phaeopigments determination, Archive für Hydrobiologie, 14, 14-36.

24. O’Hare M. T., Gunn I. D. M., Chapman D. S., Dudley B. J. and Purse B. V., 2012 - Impacts of space, local environment and habitat connectivity on macrophyte communities in conservation lakes, Diversity and Distributions, 18, 603-614.

25. Onciu T. M., Radu A. and Galaţchi L., 1999 - Contributions to the knowledge of the zooplankton from the Olt River, Transylvanian Review of Systematical and Ecological Research, 1, 67-76.

26. Pielou E. C., 1975 - Ecological diversity, John Wiley, New York, 165.

27. Raij B. V., Andrade J. C., Cantarelle H. and Quaggio J. A., 2001 - Chemical analysis for evaluation of fertility of tropical soils, Instituto Agronômico, Campinas, SP, Brazil. (in Portuguese)

28. Sipaúba-Tavares L. H. and Dias S. G., 2014 - Water quality and communities associated with macrophytes in a shallow water-supply reservoir on an aquaculture farm, Brazilian Journal of Biology, 74, 2, 420-428.

29 STATSOFT, 2011 - Inc. STATISTICA, ver. 10.

30. Villamagna A. M. and Murphy B. R., 2009 - Ecological and socio-economic impacts of invasive water hyacinth (Eichhornia crassipes): a review, Freshwater Biology, 55, 2, 282-298.

31. Zeng J., Bian Y., Xing P. and Wu Q. L., 2012 - Macrophyte species drive the variation of bacterioplankton community composition in a shallow freshwater lake, Applied and Environmental Microbiology, 78, 1, 177-184. 